\title{
Translating Ellipsis: Rendering the Missing Elements
}

\author{
Try Kurniawati Assalam ${ }^{1}$, Bayu Budiharjo ${ }^{2}$ \\ \{tryassalam@student.uns.ac.id ${ }^{1}$, budiharjo b@staff.uns.ac.id $^{2}$ \}
}

Universitas Sebelas Maret, Surakarta, Indonesia ${ }^{1,}$, Universitas Sebelas Maret, Surakarta, Indonesia ${ }^{2}$

\begin{abstract}
Ellipsis is one of the phenomena worth studying under Translation Studies. Ellipsis requires a translator not only to precisely figure out what is left-out in constructions but also to opt between keeping the ellipsis within the constructions in the target language (TL) and filling the gap with the precise information. Furthermore, translator needs to think through another essential thing, the information has to be rendered in the TL. This paper studies the translation of English elliptical constructions in the novel Percy Jackson: The Last Olympian. Sentences containing ellipses in the novel were analysed and the preliminary findings reveal the following: English and Indonesian share some identical ways of expressing elliptical constructions under particular circumstances, yet different in others. In addition, different steps are taken by the translator in dealing with elliptical constructions: using the same form of ellipsis, translating into different type of ellipsis, and making the left-out elements apparent.
\end{abstract}

Keywords: English - Indonesian Translation, ellipsis, elliptical constructions, forms

\section{Introduction}

Ellipsis phenomena which also known as omission, include a number of occurrences where otherwise referred information goes missing under certain circumstances [1]. Apart from the ellipsis that appears in discourse as a fairly common cohesive device, in many cases, literary utterance also applies an ellipsis construction to avoid unnecessary repetition, generate a cohesive textual relation, ensure propositional development, and enhance the communicative effectiveness [2]. Cohesion as a result of ellipsis construction is particularly common in two-party utterances, in which the second party may modify their responses to include the content of utterances of the first party without simply repeating it [2].

English has generally three types of ellipsis, namely predicate, clausal, and nominal. Since the missing elements are recognized in the structure, it can be said that the missing elements are parts of the phrases that constitute the structure of a clause or sentence. Supposed to maintain the plot cohesiveness of the whole story, the literary translator must find it is challenging to faithfully render the meaning of the elliptical construction in the text.

The translator sometimes keeps the elliptical construction of the source text (ST) into the target text (TT) but sometimes the translator also changes the structure by adding more information to make it explicit. Some of the elliptical construction in English cannot be translated into elliptical construction in Indonesian. It is due to the different linguistic characteristics of both English and Indonesian. Therefore, the translator of literary work should find the most suitable technique to translate elliptical construction to avoid the ungrammatical structure without changing the feeling that builds the story.

The translation of constructions containing ellipsis is rarely discussed by the previous researchers, especially the English into Indonesian translation. Schwarz explored the syntactic structure of hypothetical grammatical process in ellipsis constructions [3]. The phenomena of ellipsis in translation have been scrutinized by Nezam \& Pirnajmuddin, Sujono, Arhire, and Lestari [4] [5] [6] [7]. However, they only classify the ellipsis and identify the translation strategies, and 
did not discuss further the impact of the translation techniques on the quality of translation. This research will use the theory of ellipsis phenomena proposed by Craenenbroeck \& Merchant [1].

\section{Literature Review}

\subsection{Translation Definition and Problems}

According to Catford, translation is the process of converting the textual element in one language (source language) by equivalent textual element in another language (target language) [8]. In line with the previous, Nida says that translation consists of "reproducing in the receptor language the closest natural equivalent of the source language message, first, in terms of meaning and secondly in terms of style [9]." As well as Newmark states, translation is "a craft consisting in the attempt to replace a written message and/or statement in another language [10]." Moreover, the above definitions are also supported by the statement from Bell. He defines that translation is a depiction of a text in source language by a depiction of an equivalent text in target language [11]."

By various definitions above, it can be summarized that translation is the process of rendering messages and styles from the source language (SL) to the target language (TL). Besides, it is expected that a translation should be natural. This is supported by Nida and Taber that "the best translation does not sound like a translation [12]."

\subsection{Ellipsis Phenomena}

Ellipsis phenomena involve the material omission of sentence construction [1]. The missing material is replaced by nothing. This is a phenomenon of consciously leaving an element unstated which is nonetheless understood by the writer/speaker and reader/listener. This phenomenon does not comprise every case in which the reader/listener has to supply absent information. Instead, only those cases where the grammatical construction itself focuses on an element or elements that can fill the space being referred to [13].

Meanwhile, Halliday \& Hasan marked that where there is an ellipsis construction, there is a presumption in the structure that something is to be provided, or 'comprehended' [14]. A sentence or an utterance is labeled as elliptical if its structure does not reveal all the meaningful choices that are embodied in it. So, it can be taken a broad outline of the concept that ellipsis happens when a structurally necessary element is left unstated (omitted).

Ellipsis is distinguished by the structure having some 'missing' elements. The ellipsis phenomenon is also described as the deletion of elements normally required by the grammatical rules which the writer/speaker assumes to avoid unnecessary repetition, generate a cohesive textual relation, ensure propositional development, and enhance the communicative effectiveness [2].

\subsection{Types of Ellipsis}

Since the missing elements are recognized in the structure, it can be said that the missing elements are parts of the phrases that constitute the structure of a clause or sentence. The elliptical constructions can be translated into the same elliptical construction in the target text (TT). Sometimes translator also changes the constructions into non-elliptical construction considering the grammatical rules of the TT. Besides, Craenenbroeck \& Merchant further explain that English has generally three types of ellipsis, namely predicate, nominal, and clausal [1].

\subsection{Problems of Translating Ellipsis}

Regarding translation problems, a translator often has problems with ecological issues (ecology), socio-cultural issues (characteristics of social culture), material cultural issues (characteristics of material culture), religious issues (characteristics of religious culture), and linguistic issues (characteristics of language) [9]. 
Of the aforementioned issues regarding problems potentially faced by translators, rendering the message behind elliptical construction is within the coverage of the linguistic issue. Translating elliptical construction form English to Indonesian may become increasingly challenging for a translator because the linguistic concept of both languages is different. For example, in English, predicate ellipsis may include auxiliary verb. However, grammatical construction in Indonesian language does not recognize auxiliary verb. If the translator does not understand the linguistic rules of both SL and TL, the translation may become ungrammatical. It reduces the level of acceptability of the translation.

Furthermore, translating elliptical construction may become problematic for a translator who is required to faithfully translate the meaning of the sentence. The incomplete clause or sentence refers to the previous utterance. The omitted element can be identified by linking the ellipsis to the context. The context is constructed by all of the supporting sentences and structures in the text. In literary works, the context can be identified after figuring out the story thoroughly and accurately. If the translator cannot apprehend the story and grasp the context, the translator will find it difficult to translate clauses and sentences containing ellipsis found in the text. The problem will increase the risk and reduce translation quality, especially in terms of accuracy and readability. In order to avoid mistranslation and minimize the risk, the translator must understand the concept of ellipsis phenomena in both SL and TL.

\section{Methodology}

This research uses descriptive qualitative method aiming to reveal how English elliptical constructions in the studied novel are translated into Indonesian. The data take the form of sentences with parts constituting them omitted and their counterparts in the TL, collected through careful reading of the English novel and its Indonesian translation. The data were selected from the two novels and the remaining parts of the novel are considered as the parts providing the context in the analysis. The selected elliptical constructions were then classified into categories. The classification of elliptical constructions refers to Craenenbroeck \& Merchant's theory of ellipsis phenomena [1]. The original constructions and their translations in the TL were then compared to see how the sentences containing omitted elements are translated. The analysis was then followed by the conclusion drawing relying on the acquired findings.

\section{Findings and Discussion}

Based on all the data collected from the novel, some principal points are identified. Different ways are taken by the translator to establish equivalence in the case if translation of elliptical constructions. The translation cases can be highlighted into the following list. The aforementioned points are decided based on the types of ellipsis.

\subsection{Predicate Ellipsis}

Table 1. Predicate Ellipsis to Predicate Ellipsis

\begin{tabular}{lll}
\hline ST & TT & \\
\hline I nodded. I didn't like talking about & Aku mengangguk. Aku tak suka \\
it, but Rachel knew. & membicarakannya, tapi Rachel tahu. \\
\hline
\end{tabular}

The datum above is an instance of predicate ellipsis. The predicate of the clause above is omitted to prevent repetitive information. The writer of ST does not explain what Rachel knows. The leftout information can be revealed as the sentence is linked to the two previous sentences. The 
translator does not make any change and keeps the elliptical structure by translating the expression as it is in the TL. The additional information is not introduced in the TL.

Table 2. Predicate Ellipsis to Predicate Ellipsis + different form

\begin{tabular}{ll}
\hline ST & TT \\
\hline "Yes, but in all fairness, I don't & "Ya, tapi sejujurnya, aku tidak tahu \\
know how that will affect the spirit & bagaimana hal itu \\
of the Oracle. A woman who has & akan memengaruhi roh sang Oracle. \\
already borne a child-as far as I & Seorang wanita yang sudah pernah \\
know, this has never been done & melahirkan anak—sejauh yang \\
before. If the spirit does not take-" & kutahu, ini tidak pernah dilakukan \\
"It will," May insisted. & sebelumnya. \\
No, I wanted to shout. It won't. & Jika arwahnya tidak mau menerima-“ \\
& "Ia pasti mau," May berkeras. \\
& Nggak, aku ingin berteriak. Ia nggak \\
& akan mau. \\
\hline
\end{tabular}

Table 2. above contains two elliptical constructions of sentence predicate type. The elements of ST in italic are incomplete constructions. The modal and its negation "will" and "won ' $t$ " in both constructions can be linked to the previous sentences. They leave out the main verb "take". The complete expressions are "It will take" and "It won't take". The translation, still takes the elliptical construction form but a different one. The one-to-one correspondence of the clause "It will" is "Ia akan" but the translator chooses "Ia pasti mau" [It will surely want to] as the equivalent. Meanwhile, the one-to-one correspondence of the clause "It won't" is "Ia nggak akan" but the translator translates the original expression into "Ia nggak akan mau” [It won't want to]. The decision made by the translator results in a more natural translation.

\subsection{Nominal Ellipsis}

Table 3. Nominal Ellipsis to Nominal Ellipsis

\begin{tabular}{ll}
\hline ST & TT \\
\hline Besides, I seriously needed a & Lagi pula, aku betul-betul butuh \\
vacation. This summer had been the & liburan. Musim panas ini adalah yang \\
hardest of my life. The idea of & terberat dalam hidupku. Gagasan \\
taking a break even for a few days & $\begin{array}{l}\text { untuk ambil cuti selama beberapa } \\
\text { was really tempting. }\end{array}$ \\
\hline
\end{tabular}

The ST sentence in italic incorporates elliptical construction, a nominal ellipsis. The exclusion of "summer" avoids repetition in the same sentence as it has been stated before. The non-elliptical statement is "This summer had been the hardest summer of my life". The ST was translated into Indonesian as it is, ending up in grammatically correct expression which sounds natural.

Table 4. Nominal Ellipsis to Non-Ellipsis

\begin{tabular}{ll}
\hline ST & TT \\
\hline Rachel didn't hide much. & $\begin{array}{l}\text { Rachel tidak menyembunyikan banyak } \\
\text { hal. }\end{array}$ \\
\hline
\end{tabular}

The ST sentence contains ellipsis categorized into nominal ellipsis. The sentence contains a left-out noun phrase. The translator amplifies the translation by adding a word, hal [thing] to put the sentence in its complete form. The non-elliptical construction of the sentence in the ST is "Rachel didn't hide things much."

Table 5. Nominal Ellipsis to Non-Ellipsis

\begin{tabular}{ll}
\hline ST & TT \\
\hline
\end{tabular}




\begin{tabular}{ll}
\hline I had just attached a second jar of & Aku baru saja menempelkan toples api \\
Greek fire to the control panels & Yunani kedua ke panel kendali ketika \\
when I heard the pounding of feet & aku mendengar langkah kaki di anak \\
on metal steps-so many creatures & tangga logam-banyak sekali makhluk \\
coming down the stairwell I could & menuruni tangga sehingga aku bisa \\
hear them over the engines. Not a mendengar suara mereka melampaui \\
good sign.
\end{tabular}

The sentence above also contains ellipsis categorized into nominal ellipsis. Different from the ST, the translation does not contain ellipsis construction. The non-elliptical sentence is supposed to be "... I could hear them making noise over the engines." The noun phrase omitted in this category is in the form of gerund. It is quite different from the previous category even though both categories comprehend nominal ellipsis into non-ellipsis form.

Table 6. Nominal Ellipsis to Nominal Ellipsis + different form

\begin{tabular}{lll}
\hline ST & TT & \\
\hline Then he threw me another essential & Lalu dia melemparkan satu lagi \\
tool of demigod heroes-duct tape. & perlengkapan esensial blasteran \\
"Slap that one on the console," he & $\begin{array}{l}\text { kepadaku-selotip. "Tempelkan ke } \\
\text { said. "I'll get the turbines." }\end{array}$ \\
& $\begin{array}{l}\text { konsol," katanya. "Akan kuurus } \\
\text { turbinnya." }\end{array}$ \\
\hline
\end{tabular}

The elliptical construction in the sentence above is categorized into nominal ellipsis which is translated into elliptical construction as well but in different form. The complete expression in the ST is "Slap that one essential tool of demigod heroes (duct tape) on the console". The ST is translated into "Tempelkan ke konsol" [attach to the console]. It is still classified as nominal ellipsis but it can be seen that the translator does not choose the one-to-one correspondence of the translation.

\subsection{Clausal Ellipsis}

Table 7. Clausal Ellipsis to Clausal Ellipsis

\begin{tabular}{lll}
\hline ST & TT \\
\hline "Okay," I said. "Just a normal & "Oke,” kataku. "Cuma siang yang \\
afternoon and two normal people." & $\begin{array}{l}\text { normal dan dua orang normal." } \\
\text { She nodded. }\end{array}$ \\
\hline
\end{tabular}

The sentence containing clausal ellipsis construction above loses the noun phrase as a subject and verb phrase as a predicate. The complete construction is supposed to be "That will be just a normal afternoon and two normal people." The clause is translated into Indonesian as it is. The translation is categorized into clausal ellipsis as well.

Table 8. Clausal Ellipsis to Clausal Ellipsis + different form

\begin{tabular}{ll}
\hline ST & TT \\
\hline "Time?" I asked. & "Sudah waktunya?" tanyaku. \\
He nodded grimly. & Dia mengangguk muram. \\
\hline
\end{tabular}

The elements of ST in italic above contains an elliptical constructions of clausal type. The complete construction of the interrogative form above should be "Is it the time?" The translation still takes the elliptical construction but a different one. The translator chooses "sudah waktunya?" [It is time] instead of "waktu?" [time?] as the equivalent. The decision made by the translator results in a more natural translation.

Table 9. Clausal Ellipsis to Non-Ellipsis

\begin{tabular}{ll}
\hline ST & TT \\
\hline
\end{tabular}




\begin{tabular}{ll}
\hline We sat next to the goddess. & Kami duduk di sebelah sang dewi. \\
"Lady Hestia," I said. & "Dewi Hestia," kataku. \\
"Hello, Percy Jackson," the goddess & "Halo, Percy Jackson," gumam sang \\
murmured. "Getting colder. Harder & dewi. "Rasanya semakin dingin. Sulit \\
to keep the fire going." "I know," I & $\begin{array}{l}\text { untuk menjaga agar api tetap } \\
\text { menyala." "Aku tahu,"kataku. }\end{array}$ \\
\hline
\end{tabular}

The table 9. above contains ellipsis of clausal type. The sentence of ST typed italic has incomplete structure of predicate and nominal. The complete structure of the sentence is "It's getting colder. It's harder to keep the fire going." The translator translates it into "Rasanya semakin dingin. Sulit untuk menjaga agar api tetap menyala" [It feels colder. It's hard to keep the fire burning] which does not belong to elliptical construction in Indonesian. This case may occur due to the linguistic issue of the languages.

This study suggests that elliptical constructions are features of both source and target languages. Similarities are revealed that some very same forms of elliptical linguistic constructions communicate equivalent message and thus the expressions in the target language can serve as equivalent of the original. Also, differences are identified in cases where elliptical constructions in the source language require modification to function as counterparts of the original.

Different ways of rendering meaning of elliptical construction are also identified in a research investigating English to Persian translation of ellipsis in Hemmingway's The Old Man and the Sea [6]. This research reveals that a great number of English elliptical constructions are translated into equivalent elliptical constructions in the TL. The other ways are the expansion and deletion of elliptical elements. The ways elliptical constructions are translated in both pieces of research share similarities but in the study of English - Persian translation, the preservation of elliptical constructions in the target language is not further specified whether the elliptical costructions in both languages are made up of identical elements or not.

Difference between the grammar of the SL and that of TL forces translator on many occasions to opt for different way of conveying message other than producing similar constructions in the target language. This happens in English - Romanian translation as revealed by Arhire and in this investigation that we conducted. As the ellipses means marking identity of literary characters, compensation is often chosen as the way to deal with such situation [4]. In comparison, ellipses of different forms and non-elliptical constructions are proven to be relied on in the different situation and pairs of language.

Another different situation is proven in a study by Izwaini and Al-Omar to prompt different translation of ellipsis [15]. In the study investigating substitution and ellipsis in the context of English - Arabic subtitle, repetition and addition are favored in the attempt to maintain cohesion although the use of the two is against the brevity principle in subtitling.

\section{Conclusion}

The source language elliptical constructions studied are translated into the TL in different ways. The elliptical form in the ST is either preserved (in which elliptical construction is chosen as the equivalent) or converted (in which the left-out element is noticeably exposed). The former is further branched into two: preservation by elliptical construction of similar structure and the one using different structure.

\section{References}

[1] Craenenbroeck, Merchant J. Ellipsis phenomena. In: den Dikken M, editor. The Cambridge Handbook of Generative Syntax. Cambridge: Cambridge University Press; 2013. p. 701-45.

[2] McShane M. A theory of ellipsis. New York: Oxford University Press; 2005.

[3] Schwarz B. Topics in ellipsis. Doctoral Dissertations Available from Proquest. AAI9960789. 2000. https://scholarworks.umass.edu/dissertations/AAI9960789 
[4] Arhire M. The translation of ellipsis as identity marker in the literary dialogue. AUS Philolo. 2018; 10(3):19-32.

[5] Lestari D. Strategies for ellipsis translation in phrase level in Mandy Hubard's prada and prejudice. Undergraduate Thesis, Universitas 17 Agustus 1945. 2018.

[6] Nezam A, Pirnajmuddin H. Translation of ellipsis as a stylistic feature: Hemingway's The Old Man and the Sea and its Persian translations. J Lang Teach Res. 2012; 3(6):1250-1257.

[7] Sujono A. The translation of ellipsis and event reference in JK Rowling's Harry Potter and the goblet of fire. UNS J Lang Sci. 2014;03(1):1-13.

[8] Catford J. A linguistic theory of translation: an essay in applied linguistics. Oxford: Oxford University Press; 1969.

[9] Nida E, Taber C. The theory and practice of translation. Leiden: E.J. Brill; 1969.

[10] Newmark P. A textbook of translation. New Jersey: Prentice-Hall International; 1988.

[11]Bell R. Translation and translating: Theory and practice. New York: Longman; 1991.

[12] Nida E, Taber C. The theory and practice of translation. Leiden: E.J. Brill; 1974.

[13] Baker M. In other words: a coursebook of translation. New York: Routledge; 1992.

[14] Halliday M, Hasan R. Cohesion in English. London: Longman; 1976.

[15] Izwaini S, Al-Omar H. The translation of substitution and ellipsis in Arabic subtitling. J Audio Trans. 2019; 2(1):126-151. 